\title{
Surface Temperature Distribution in Broiler Houses
}

-Author(s)

Baracho MS

Nääs IA

Nascimento GR

Cassiano JA

Oliveira KR

School of Agriculture Engineering - FEAGRI/ UNICAMP.

\section{-Mail Adress}

MS Baracho

E-mail: martbaracho@yahoo.com.br

\section{-Keywords}

Broiler production, housing, infrared thermography.

\section{-Acknowledgements}

This study was supported by the Brazilian National Council of Research and Development (CNPq).

\begin{abstract}
In the Brazilian meat production scenario broiler production is the most dynamic segment. Despite of the knowledge generated in the poultry production chain, there are still important gaps on Brazilian rearing conditions as housing is different from other countries. This research study aimed at analyzing the variation in bird skin surface as function of heat distribution inside broiler houses. A broiler house was virtually divided into nine sectors and measurements were made during the first four weeks of the grow-out in a commercial broiler farm in the region of Rio Claro, São Paulo, Brazil. Rearing ambient temperature and relative humidity, as well as light intensity and air velocity, were recorded in the geometric center of each virtual sector to evaluate the homogeneity of these parameters. Broiler surface temperatures were recorded using infrared thermography. Differences both in surface temperature (Ts) and dry bulb temperature (DBT) were significant $(p<0.05)$ as a function of week of rearing. Ts was different between the first and fourth weeks $(p<0.05)$ in both flocks. Results showed important variations in rearing environment parameters (temperature and relative humidity) and in skin surface temperature as a function of week and house sector. Air velocity data were outside the limits in the first and third weeks in several sectors. Average light intensity values presented low variation relative to week and house sector. The obtained values were outside the recommended ranges, indicating that broilers suffered thermal distress. This study points out the need to record rearing environment data in order to provide better environmental control during broiler grow-out.
\end{abstract}

\section{INTRODUCTION}

Broiler production is an important item of Brazilian exports, and it is becoming increasingly dynamic. The concept of thermal comfort is related to the birds' rearing environment, especially in open-sided or curtain-sided poultry houses. Exposure to heat stress impairs live production as it reduces the bird's ability to exchange sensible heat with its surroundings (Morrow, 2001; Moura, 2001; Abu-Dieyeh et al., 2006). Increase in air velocity by the use of fans may alleviate heat stress (Yahav et al., 2001 and 2004) as it increases heat loss by convection.

Due to the thick insulation provided by the feather coat on most of the body surface, broiler sensible heat loss is more efficient in featherless body areas, where blood flow increases when birds are exposed to heat stress. Broilers exposed to heat stress significantly decreased blood flow to heat-exchange organs and skin surface (Borges et al., 2003; Altan et al., 2003), which results in lower sensible heat loss from the extremities and featherless areas, increasing metabolic expenditure to regulate body temperature (Oliveira Neto et al., 2000; Furlan \& Macari, 2002). 
The use of infrared thermography allows identifying spots with different radiant temperatures, and it is a valuable tool for recognizing physiological abnormalities in humans and animals. Surface temperature can be measured from a distance with high precision, especially on animal coats with low heat capacities, and it does not disturb the animals (Richards, 1971; McCafferty et al., 1998).

This study aimed at analyzing broiler surface temperature variation as function of the ambient data fluctuation during the first four weeks of rearing of two different flocks.

\section{MATERIAL AND METHODS}

The study was carried out in a commercial broiler farm located in the region of Rio Claro, state of São Paulo (longitude 47 $37^{\prime} 52^{\prime \prime} \mathrm{W}$ and latitude $22^{\circ} 24^{\prime} 54^{\prime \prime}$ S), Brazil, using two flocks between one and 28 days of age. Data was recorded and analyzed weekly on days $7,14,21$, and 28 of the grow-out during the periods of March to April 2009 (flock 1 with 20,200 birds), and May to June 2009 (flock 2, with 20,000 birds).

The broiler house was $12 \mathrm{~m}$ wide, $120 \mathrm{~m}$ long and $3 m$ high, with concrete poles at every $8 m$ in the length. The roof was made of fibercement tiles, and had polyethylene canvas ceiling. Tunnel ventilation was used for air cooling and exchange using exhaustion fans placed on the west of the building; and the inlet with evaporative cooling pads were placed on the east side. The side walls were made of blue polyethylene curtains on the inside and white on the outside. Rice hulls and wood shavings were used as litter material. Brooding during the starter phase was provided by natural gas heaters.

The broiler house was virtually divided into nine sectors, which were modified as birds grew in order to properly register the variation in ambient data (Figure 1). Environmental variables (dry bulb temperature$\mathrm{DBT}$, and relative humidity- $\mathrm{RH}$ ) were recorded using the thermal stress monitor Questemp ${ }^{\circledR} 34$ in each geometrical center of the nine sectors.

In the same place ambient data and surface temperature of broilers were recorded using infrared thermography (Termovisor Testo ${ }^{\circledR}$ 880-St). Air velocity was recorded using a digital thermo hygroanemometer and light intensity was recorded using the digital luxmeter $\left(\mathrm{HOMIS}^{\circledR}\right)$, as suggested by Jones et al. (2005) and Bessei (2006), respectively.

Total sensible heat loss (Q) was calculated (Eq 1) as function of heat loss by radiation $(Q R)$ and by convection (QC), as suggested by Yahav et al. (2004) and Van Brecht et al. (2005), respectively (Eq. 2 and 3).

\begin{tabular}{|c|c|c|c|}
\hline 9 & 6 & 3 & $E$ \\
\hline 8 & 5 & 2 & E \\
\hline 7 & 4 & 1 & \\
\hline $40 \mathrm{~m}$ & & & \\
\hline
\end{tabular}

Figure 1 - Scheme of the broiler house, showing the sectors where data were collected.

$$
\begin{aligned}
& Q=Q_{R}+Q_{C} \\
& Q_{R}=e \sigma A\left(T_{s}{ }^{4}-T_{\text {air }}{ }^{4}\right) \\
& Q_{C}=h A\left(T_{s}-T_{\text {air }}\right) \\
& h=0.3364 .184\left(1.46+\sqrt{ } V_{\text {air }}-100\right)
\end{aligned}
$$

Where $\mathrm{Q}=$ total sensible heat $(\mathrm{W})$, e = bird emissivity (0.95), $\sigma=$ Stefan-Boltzman constant $\left(5.67 \mathrm{~m}^{-2} \times 10^{-8}\right.$, $\left.\mathrm{W} \mathrm{m}^{-2} \mathrm{~K}^{-4}\right), A=$ bird surface area $\left(\mathrm{m}^{2}\right)$, and $\mathrm{h}=$ heat transfer coefficient given by Eq. $4\left(15 \mathrm{~W} \mathrm{~m}^{-2} \mathrm{C}\right)$, Vair= air velocity, $\mathrm{Qr}=$ heat loss by radiation $(\mathrm{W}), \mathrm{Qc}=$ heat loss by convection (W), $\varepsilon=$ emissivity of biological tissue, Ts = bird's surface temperature $(C)$, and Tair $=$ air temperature $(C)$. The area $\left(A, m^{2}\right)$ in Eq. 2 and Eq. 3 was estimated as the average area of a spherical form exposed to convective and radiant heat transfer. The software Surfer ${ }^{\circledR}$ version 8.02 was used to map surface temperature data $\left(\mathrm{Ts},{ }^{\circ} \mathrm{C}\right)$ and ambient dry bulb temperature $\left(\mathrm{DBT},{ }^{\circ} \mathrm{C}\right)$.

Data were analyzed using one-way ANOVA and 95\% statistical significance level was adopted. Paired Tukey test was used to compare the results.

\section{RESULTS AND DISCUSSION}

Table 1 presents broiler surface temperature (Ts, ${ }^{\circ} \mathrm{C}$ ) and ambient dry bulb temperature $\left(\mathrm{DBT},{ }^{\circ} \mathrm{C}\right)$ data according to the studied sectors.

Differences were significant $(p<0.05)$ both in surface temperature (Ts) and dry bulb temperature (DBT) between weeks, and Ts results were significantly different between the first and fourth week $(p<0.05)$ in both flocks (Table 2). This results were expected as surface temperature is a direct result of environmental 
Baracho MS, Nääs IA, Nascimento GR,

Table 1 - Broiler surface temperature $\left(T s,{ }^{\circ} \mathrm{C}\right)$ and ambient dry bulb temperature $\left(\mathrm{DBT},{ }^{\circ} \mathrm{C}\right)$ per house sector and grow-out week in flocks 1 and 2 .

\begin{tabular}{|c|c|c|c|c|c|c|c|c|c|c|c|c|c|c|c|c|}
\hline \multirow{3}{*}{$\begin{array}{l}\text { Flock } \\
\text { Sector }\end{array}$} & \multicolumn{16}{|c|}{ Mean temperature variation per grow-out week } \\
\hline & \multicolumn{2}{|c|}{ Ts1 } & \multicolumn{2}{|c|}{ DBT1 } & \multicolumn{2}{|c|}{ Ts2 } & \multicolumn{2}{|c|}{ DBT 2} & \multicolumn{2}{|c|}{ Ts3 } & \multicolumn{2}{|c|}{ DBT3 } & \multicolumn{2}{|c|}{ Ts4 } & \multicolumn{2}{|c|}{ DBT4 } \\
\hline & 1 & 2 & 1 & 2 & 1 & 2 & 1 & 2 & 1 & 2 & 1 & 2 & 1 & 2 & 1 & 2 \\
\hline 1 & 25.5 & 34.2 & 25.9 & 24.5 & 24.7 & 31.3 & 27.2 & 21.5 & 24.8 & 30.4 & 25.7 & 20.6 & 24.6 & 29.0 & 24.8 & 19.4 \\
\hline 2 & 27.2 & 34.5 & 26.4 & 27.2 & 27.5 & 30.7 & 28.0 & 22.7 & 24.8 & 32.6 & 25.5 & 20.7 & 27.1 & 30.5 & 25.2 & 20.2 \\
\hline 3 & 26.3 & 34.1 & 26.8 & 27.3 & 26.4 & 30.7 & 29.3 & 23.4 & 26.0 & 31.6 & 25.9 & 22.3 & 26.0 & 30.4 & 26.1 & 20.7 \\
\hline 4 & 28.4 & 32.8 & 27.4 & 23.3 & 27.5 & 31.1 & 27.6 & 23.0 & 26.1 & 32.6 & 27.2 & 23.3 & 25.6 & 28.8 & 28.0 & 22.3 \\
\hline 5 & 28.3 & 34.8 & 27.9 & 27.9 & 29.2 & 32.6 & 29.0 & 24.6 & 26.9 & 35.4 & 27.3 & 23.0 & 26.1 & 33.0 & 28.2 & 23.0 \\
\hline 6 & 26.0 & 36.5 & 27.9 & 28.2 & 29.5 & 32.5 & 29.8 & 25.5 & 27.5 & 32.5 & 27.3 & 24.1 & 24.1 & 31.6 & 26.7 & 24.1 \\
\hline 7 & 27.0 & 34.4 & 28.2 & 24.5 & 27.4 & 33.1 & 27.3 & 23.9 & 26.5 & 31.9 & 27.5 & 23.7 & 25.6 & 30.9 & 27.6 & 23.6 \\
\hline 8 & 26.4 & 35.3 & 27.7 & 26.4 & 28.0 & 32.8 & 28.5 & 24.6 & 26.2 & 31.1 & 27.4 & 23.8 & 25.8 & 32.1 & 27.6 & 23.6 \\
\hline 9 & 26.2 & 35.5 & 27.9 & 28.2 & 28.0 & 33.3 & 29.5 & 25.6 & 27.3 & 33.5 & 27.3 & 24.7 & 25.6 & 32.6 & 27.4 & 23.8 \\
\hline Ave week $^{-1}$ & 26.81 & 34.7 & 27.34 & 26.4 & 27.58 & 32.0 & 28.47 & 23.9 & 26.23 & 32.4 & 26.79 & 22.9 & 25.61 & 31.0 & 26.84 & 22.3 \\
\hline$\Delta \mathrm{t}$ & 0.53 & 8.3 & & & 0.89 & 8.1 & & & 0.56 & 9.5 & & & 1.23 & 8.7 & & \\
\hline
\end{tabular}

$\Delta \mathrm{t}=$ TBS-Ts. DBT- dry bulb temperature. Ts-surface temperature.

exposure and DBT variation was similar in the second to third and fourth week $(p<0.05)$. Temperature difference between Ts and DBT varied among weeks. DBT and Ts distributions were also different among house sectors (Figures 2 and 3).

Because sensible heat is directly related to temperature differences (Yahav et al., 2001 and 2004), excessive heat loss occurred during the first weeks of the grow-out. According to Yahav et al. (2004) the gradient between ambient and bird surface temperature determines sensible heat exchange, which is used as an input in the calculation of forced ventilation systems.

Table 2 - Birds surface temperature during the four grow-out weeks of growth in flocks 1 and 2 .

\begin{tabular}{cccc}
\hline \multirow{2}{*}{ Week } & \multicolumn{2}{c}{ Flock surface temperature $\left(\mathbf{T s}^{\circ}{ }^{\circ} \mathbf{C}\right)$} \\
\cline { 2 - 4 } & Flock $\mathbf{1}$ & Flock $\mathbf{2}$ \\
\hline 2 & $35.9 \pm 2.0 \mathrm{a}$ & $34.7 \pm 1.8 \mathrm{a}$ \\
& 3 & $35.2 \pm 1.6 \mathrm{ab}$ & $32.0 \pm 2.2 \mathrm{ab}$ \\
& 3 & $33.7 \pm 2.5 \mathrm{ab}$ & $32.4 \pm 3.0 \mathrm{ab}$ \\
\hline Average & 4 & $33.0 \pm 2.6 \mathrm{~b}$ & $31.0 \pm 3.0 \mathrm{~b}$ \\
\hline
\end{tabular}

Tukey's test (95\%).

Surface temperature was higher in flock 2 (Table 2). The calculation of Pearson's correlation between ambient dry bulb temperature and broiler surface temperature response showed moderate correlation (0.44, for flock 2 data) between bird surface temperature (Ts) and the ambient temperature (DBT). This result indicates that rearing ambient conditions were not favorable to broiler growth, according to Altan et al. (2003) and Borges et al. (2003). Table 3 shows that there was no effect on broiler performance in neither of the flocks, considering daily gain weight and feed conversion. Mortality was higher in flock 1 $(5.6 \%)$ as compared to flock $2(3.5 \%)$ probably due to the number of reared birds.

Table 3 - Mean broiler performance results.

\begin{tabular}{lcc}
\hline & \multicolumn{2}{c}{ Flock surface temperature $\left(\mathbf{T s}^{\circ}{ }^{\circ} \mathbf{C}\right)$} \\
\cline { 2 - 3 } & Flock 1 & Flock 2 \\
\hline Number of reared birds & 20,200 & 20,000 \\
Mortality (\%) & 5.6 & 3.5 \\
Daily weight gain (g) & 61.6 & 60.58 \\
Feed conversion ratio & 1.7 & 1.7 \\
\hline
\end{tabular}

This indicates birds were probably using extra energy to maintain their body temperature, especially in flock 2, as $\Delta \mathrm{t}\left[{ }^{*} 1\right]$ values significantly increased during rearing (Bootje \& Harrison, 1985; Chepete et al., 2005).

Recorded rearing ambient data were compared to the recommended values in literature (Albright, 1990; Moura, 2001), and the results (Table 4) indicate some degree of bird distress, as the recorded values were different from the optimal recommendations, which may explain the worse final performance indexes (Bootje \& Harrison, 1985; Macari et al., 1998; Owada et al., 2007). Sevegnani (1997) pointed out the negative effects on broiler production when the housing conditions do not provide adequate thermal environment or air exchange, causing thermal discomfort in the birds.

The DBT values recorded in different house sectors during the studied grow-out weeks (Table 4) were higher than those recommended in current literature, which may have negatively affected broiler growth and performance (Chepete et al., 2005). Research in this field indicates that increases in broiler body 

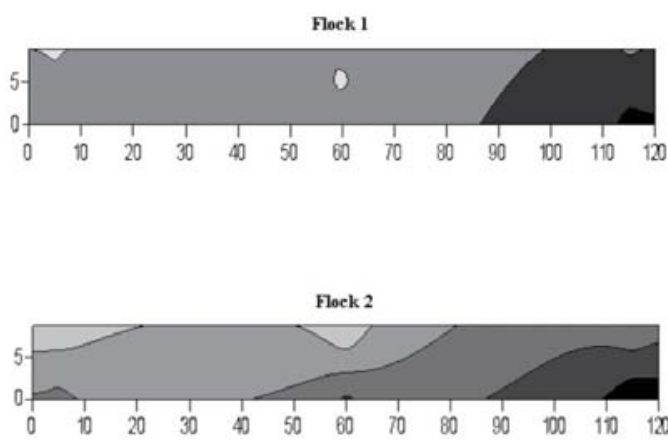

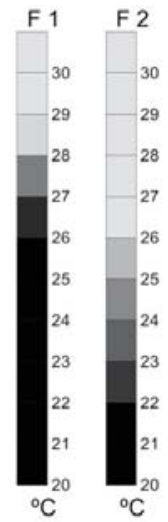

Figure 2 - Dry bulb temperature distribution inside the poultry house during the grow-out of flocks 1 and 2 .
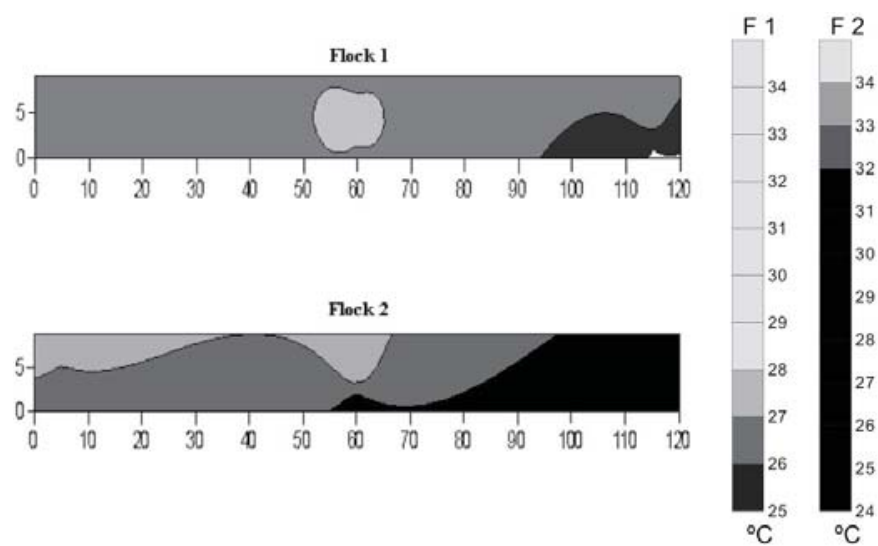

Figure 3 - Surface temperature distribution inside the poultry house during the grow-out of flocks 1 and 2 . temperature may cause significant broiler performance losses (Ain Baziz et al., 1996) and increase both in feed and water consumption attempting to maintain stable body core temperature (Smith \& Teeter, 1993).

Relative humidity values were within acceptable range (50-70\%) in flock 1 and 2, but above the recommended levels (Table 4 ).

Air velocity data were beyond the recommended threshold in the first and third week in several house sectors. According to Moura (2001), this may have negatively impact performance. Tao \& Xin (2003) recommend air velocities between 0.2 and $1.2 \mathrm{~m}$ $\mathrm{s}^{-1}$ inside broiler houses and Sevegnani et al. (2005) proposes values between 0.3 and $1.0 \mathrm{~m} \mathrm{~s}^{-1}$ for adult birds. However, lower limits are adequate to chicks during their first weeks of life. According to Yahav et al. (2001), sensible heat loss by broilers exposed to a certain range of air velocities $\left(0.8-2.5 \mathrm{~m} \mathrm{~s}^{-1}\right)$ may be significantly different, although sensible heat loss by convection is higher when the air velocity increases.

Average light intensity values showed low variation as a function of week and house sector. Relative humidity, air velocity and light intensity results are shown in Table 5 . The average difference in surface temperature between flocks 1 and 2 was nearly $3{ }^{\circ} \mathrm{C}$ $(34.5 \pm 2.5$ in flock 1 and $32.5 \pm 3.2$ in flock 2$)$.

The assessment of heat loss by radiation (Qr), convection (Qc), and total sensible heat loss (Qt) of both flocks are shown in Figure 4. There was a variation temperature are usually proportional to increases in the ambient temperature. Boone \& Hughes (1971) found that pullet body temperature is soundly regulated when ambient temperature is around $30^{\circ} \mathrm{C}$; however, when DBT increases in $5^{\circ} \mathrm{C}$, birds present a significant reduction in their capacity to exchange sensible and latent heat, leading to low feed intake, and eventually, to death. This variation in surface
Table 5 - Relative humidity, air velocity and light intensity (mean \pm standard deviation) recorded during the four studied grow-out weeks in the two flocks.

\begin{tabular}{lccccc}
\hline & \multirow{2}{*}{ Flock } & \multicolumn{5}{c}{ Week } \\
\cline { 3 - 6 } & & $\mathbf{1}$ & $\mathbf{2}$ & $\mathbf{3}$ & $\mathbf{4}$ \\
\hline \multirow{2}{*}{ Relative humidity (\%) } & 1 & $67.1 \pm 5.4$ & $66.6 \pm 4.6$ & $67.1 \pm 6.1$ & $56.5 \pm 3.4$ \\
& 2 & $61.4 \pm 5.1$ & $62.0 \pm 5.2$ & $60.0 \pm 3.0$ & $64.0 \pm 6.3$ \\
\hline \multirow{2}{*}{ Air velocity $\left(\mathrm{m} \mathrm{s}^{-1}\right)$} & 1 & $0.28 \pm 0.2$ & $0.79 \pm 0.3$ & $1.1 \pm 0.5$ & $2.0 \pm 0.4$ \\
& 2 & $0.25 \pm 0.2$ & $0.5 \pm 0.2$ & $0.5 \pm 0.3$ & $0.7 \pm 0.3$ \\
\hline \multirow{2}{*}{ Light intensity (Ix) } & 1 & $7.3 \pm 3.2$ & $6.9 \pm 1.9$ & $6.6 \pm 2.0$ & $7.0 \pm 2.6$ \\
& 2 & $11.7 \pm 2.4$ & $8.2 \pm 2.2$ & $7.6 \pm 2.0$ & $5.1 \pm 1.3$ \\
\hline
\end{tabular}

Table 4 - Rearing environment parameters that presented values beyond the threshold according grow-out week and house sector.

\begin{tabular}{lcccc}
\hline & \multicolumn{5}{c}{ Week of growth } \\
\hline Rearing ambient data & $\mathbf{1}$ & $\mathbf{2}$ & $\mathbf{3}$ & $\mathbf{4}$ \\
\hline Temperature (DBT) & 7 & $3,5,68$ and 9 & & 5 \\
Relative humidity (RH) & \multicolumn{5}{c}{$1,3,8$ and $\mathbf{9}$} \\
Air velocity (Vair) & $1,2,3,4,5,6,7,8$, and 9 & & $\mathbf{3}$ & $\mathbf{4}$ \\
\hline Rearing ambient data & $\mathbf{1}$ & $\mathbf{2}$ & & 1 \\
\hline Temperature (DBT) & 6 and 9 & $1,2,3$ and 4 \\
Relative humidity (RH) & 7 and 8 & 7 & $1,2,3,456,7$ and 9 & 1 \\
Air velocity (Vair) & $3,5,6,7$ and 9 & $2,3,4,6,7$ and 8 & 1 and 8 & 3 \\
\hline
\end{tabular}

in the heat exchange during the studied weeks, and heat loss was higher in flock 2 than in flock 1. When broilers are exposed to harsh rearing environments, the gradient between average surface temperature $\left(35^{\circ} \mathrm{C}\right)$ and mean ambient temperature $\left(32^{\circ} \mathrm{C}\right)$ was low, which hinders sensible heat loss by conduction, convection 
or radiation. In this case, panting is virtually the only way birds effectively loose heat, and this physiological response demands high energy expenditure (Furlan \& Macari, 2002). However, when relative humidity is high $(>70 \%)$, this form of latent heat loss becomes ineffective (Lasiewski et al., 1966).

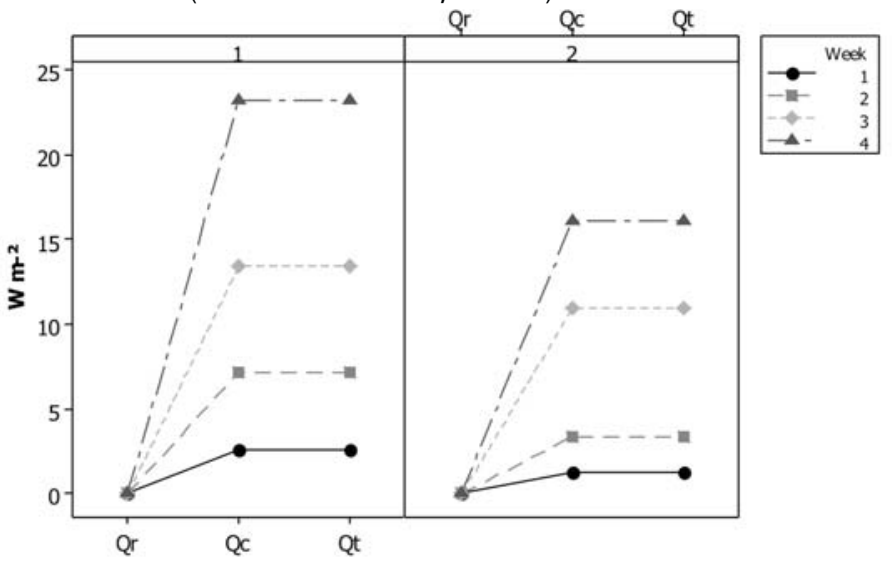

Figure 4 - Sensible heat loss by radiation (Qr), convection (Qc) and total (Qt) estimated per bird in both flocks.

\section{CONCLUSIONS}

The variation in broilers' rearing environment by sector may have influenced their surface temperature. Rearing environmental data were beyond the recommended thresholds for adequate broiler performance. This study indicates the need to properly record environmental data of the rearing environment in order to support better environmental control during broiler grow-out.

\section{REFERENCES}

Abu-Dieyeh ZHM. Effect of chronic heat stress and long-term feed restriction on broiler performance. International Journal of Poultry Science 2006; 5 (2):185-190.

Ain Baziz H, Geraert PA, Padilha JCF, Guillaumin S. Chronic heat exposure enhances fat deposition and modifies muscle and fat partition in broiler carcasses. Poultry Science 1996; 75:505-513.

Albright L. Environment control for animals and plants. St. Joseph: ASABE Textbook; 1990.

Altan O, Pabuçcuoglu A, Altan A, Konyalioglu S, Ayraktar H. Effect of heat stress on oxidative stress, lipid peroxidation and some stress parameters in broilers. British Poultry Science 2003; 44(4):545-550.

Bessei W. Welfare of broilers. Worlds Poultry Science Journal 2006; 62(3):455-66.
Boone MA, Huston T. Effect of heat stress on laying and non-laying hens Poultry Science 1971; 50:473-477.

Bottje WG, Harrison PC. Effect of carbonated water on growth performance of cockerels subjected to constant and cyclic heat stress temperatures. Poultry Science 1985; 64:1285-1292.

Borges AS, Maiorka A, Silva AVF. Fisiologia do estresse calórico e a utilização de eletrólitos em frangos de corte. Ciência Rural 2003; 33, (5):975-981.

Chepete HJ, Chimbombl E, Tsheko R. Production performance and temperature-humidity index of Cobb 500 broiler reared in open-side naturally ventilated houses in Botswana. In: Seventh International Symposium; 2005; Beijing, China. Paper n. 701P0205.

Furlan RL, Macari M. Termorregulação. In: Macari M, Furlan RL, Gonzales $\mathrm{E}$, editores. Fisiologia aviária aplicada a frangos de corte. 2. ed. Jaboticabal: FUNEP/UNESP; 2002. p. 209-230.

Jones TA, DonnellY CA, Dawkins MS. Environmental and management factors affecting the welfare of chickens on commercial farms in the United Kingdom and Denmark stocked at five densities. Poultry Science 2005; 84:1155-1165.

Lasiewski RC, Costa A, Bernstein MH. Evaporative water loss in birds. I. Characteristics of the open flow method of determination, and their relation to estimates of thermoregulatory ability. Comparative Biochemical and Physiology 1966; 19:455-457.

Macari M, Malheiros RD, Moraes VMB, Bruno LDG. Controle do ambiente objetivando a produtividade e sanidade. Conferência Apinco de Ciência e Tecnologia Avícolas; 1998; Campinas, São Paulo. Brasil. p.161-182.

McCafferty DJ, Moncrieff JB, Taylor R, Boddie GF. The use of IR thermography to measure the radiative temperature and heat loss of a barn owl (Tyto alba). Journal of Thermal Biology 1998; 23: 311-318

Morrow C. Poultry management, heath and disease in hot climates. In: Jordan F, Pattison M, Alexander D, Faragher T, editors. Poultry disease. 5thed. London: W. B. Sauders; 2001. p. 496-504.

Moura DJ. Ambiência na produção de aves de corte. In: Silva IJO, Ed. Ambiência na produção de aves em clima tropical. Piracicaba: SBEA; 2001. p.75-149.

Oliveira Neto AR, Oliveira RFM, Donzele JL, Rostagno HS, Ferreira RA, Maximiano HC, Gasparino E. Efeito da temperatura ambiente sobre o desempenho e características de carcaça de frangos de corte alimentados com dieta controlada e dois níveis de energia metabolizável. Revista Brasileira de Zootecnia 2000; 29(1):183-190.

Owada NA, Nääs IA, Moura DJ, Baracho MS. Estimativa de bemestar de frango de corte em função da concentração de amônia e grau de luminosidade no galpão de produção. Engenharia Agrícola 2007; 27(3):111-618.

Richards SA. The significance of changes in the temperature of the skin and body core of the chicken in the regulation of the heat loss. Journal of Physiology 1971; 216:1-10. 
Sevegnani KB. Avaliação de tinta cerâmica em telhados de modelo em escala reduzida, simulando galpões para frango de corte [dissertação]. Campinas(SP):Faculdade de Engenharia Agrícola, Universidade Estadual de Campinas. 74p.

Sevegnani KB, Caro IW, Pandorfi H, Da Silva IJO, Moura DJ. Zootecnia de precisão: análise de imagens no estudo do comportamento de frangos de corte em estresse térmico. Revista Brasileira de Engenharia Agrícola e Ambiental 2005, 9(1):115-119.

Smith MO, Teeter RG. Carbon dioxide, ammonium chloride, potassium chloride, and performance of heat distressed broilers. Journal of Applied Poultry Research 1993; 2:61-66.

Tao X, Xin H. Temperature-Humidity-Velocity Index for market-size broilers. In: ASABE Annual International Meeting; 2003; Nevada. USA. Paper n. 034037.

Van Brecht A, Hens $H$, Lemaire JL. Quantification of the heat exchange of chicken eggs. Poultry Science 2005; 84:353-361.

Yahav S, Straschnow A, Vax E, Razpakovski V, Shinder D. Air velocity alters broiler performance under harsh environmental conditions. Poultry Science 2001; 80:724-726.

Yahav S, Straschnow A, Luger D, Shinder D, Tanny J, Cohen S. Ventilation, sensible heat loss, broiler energy, and water balance under harsh environmental conditions. Poultry Science 2004; 83: 253-258. 